Click www.researchjournal.co.in/online/subdetail.html to purchase.

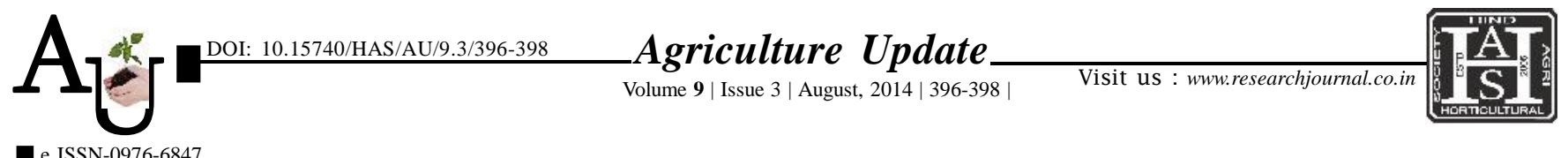

Research Article

\title{
Constraint faced by rural youth in participating activities of Adarsh Gaon Yojana
}

\author{
K.S. BHORE, J.V. EKALE AND V.N. SIDAM
}

Article Chronicle: Summary : 'Ex-post-facto' research design was adopted to identify the constraints faced by rural youth in Received :

22.11.2013;

Revised :

30.06.2014;

Accepted :

12.07.2014

\section{KeY WoRds :}

Constraints, Rural youth, Adarsh Gaon Youjana participating activities of Adharsh Gaon Yojana. Human resources our greatest potential assets which need to be cultivated for the betterment of our country. For the study, Parbhani and Osmanabad district were selected randomly, from each district two talukas, from each taluka two villages were selected where Adarsh Gaon Yojana was implemented. From each of the village fifteen numbers of respondents were selected. Thus, 120 respondents were selected for study. It was noticed that majority of respondents were having education upto college and higher education, nuclear type family, farming is main occupation, medium annual income, medium source of information and medium level of cosmopolitness and majority of respondents were having medium level of overall participation.

How to cite this article : Bhore, K.S., Ekale, J.V. and Sidam, V.N. (2014). Constraint faced by rural youth in participating activities of Adarsh Gaon Yojana. Agric. Update, 9(3): 396-398.
Author for correspondence :

\section{K.S. BHORE}

Department of

Extension Education,

Vasantrao Naik

Marathwada Krishi

Vidyapeeth, PARBHANI

(M.S.) INDIA

See end of the article for

authors' affiliations 